\title{
Research on Scientific \& Technological Achievements Transformation of Sichuan Provincial State-Owned Enterprises of China
}

\author{
Zhuxin Wu, Chunyu Zhao, Mei Chen \\ School of Business, Sichuan Normal University, Chengdu, China \\ Email: zcy@sicnu.edu.cn
}

Received 16 June 2016; accepted 9 July 2016; published 12 July 2016

Copyright (C) 2016 by authors and Scientific Research Publishing Inc.

This work is licensed under the Creative Commons Attribution International License (CC BY). http://creativecommons.org/licenses/by/4.0/

(c) (i) Open Access

\begin{abstract}
For building an innovation-oriented country, it is inevitable to speed up the scientific $\&$ technological achievements transformation. How to promote scientific \& technological achievements transformation would become the problem that all innovation subjects must face and resolve. This paper, based on the related concept of the scientific \& technological achievements transformation, and in light of the present situations of Sichuan provincial state-owned enterprises in respect of scientific \& technological achievements transformation, put forward some countermeasures and proposals concerning promotion of the scientific \& technological achievements transformation. These countermeasures and proposals include: striving to build a high-end industry chain, expanding financing channels, implementing mixed ownership reform, optimizing the structure of corporate governance, providing preferential governmental policy support, and expanding the $S \&$ $T$ insurance coverage.
\end{abstract}

\section{Keywords}

Provincial State-Owned Enterprises, Scientific \& Technological Achievements Transformation, Innovation

\section{Introduction}

Speeding up the scientific \& technological achievements transformation is the basic way to implement independent innovation strategy and transform economic development pattern, and also an effective means to enhance the economy competitiveness and promote economic growth. This is generally recognized by domestic and foreign scholars, government officials and entrepreneurs. Schumpeter's innovation theory, Arrow's "knowledge 
spillover effect”, Arthur's explanation about "lock-in effect” and research made by domestic and oversea scholars confirm that the scientific \& technological achievements transformation can promote economic growth. Since China's reform and opening up, China's economy witnessed rapid growth and development, but the S \& T innovation capability is relatively weak and most of core technologies are controlled by others. Therefore, facing rapid technological change and fierce international competition with innovation and technological upgrade as the main features, China must make such strategic choice as enhancing the independent innovation capability and building innovation-oriented country.

In recent years, China has successively introduced a variety of rules and approaches in an effort to promote scientific \& technological achievements transformation. However, regarding the efficiency and effectiveness of scientific \& technological achievements transformation, China lags far behind other developed countries. All innovation subjects, especially state-owned enterprises, fail to play their leading roles in terms of $\mathrm{S} \& \mathrm{~T}$ achievements transformation. Therefore, this paper, based on related concept of the S \& T achievements transformation, combined with the present situations of Sichuan-based state-owned enterprises regarding $S \& T$ achievements transformation, put forward some countermeasures and suggestions concerning promotion of the $\mathrm{S} \& \mathrm{~T}$ achievements transformation. It is suggested that in order to increase the efficiency and effect of transformation, it had better build a high-end industry chain, expand financing channels, implement mixed ownership reform, optimize the structure of corporate governance, provide preferential governmental policy support, and expand the $\mathrm{S} \& \mathrm{~T}$ insurance coverage.

\section{Concept of S \& T Achievements Transformation}

In general, S \& T achievements refer to the product generated by scientific \& technological activities and scientific \& technological activities include research and development, transformation and application of R \& D findings, and scientific \& technological service activities. And research and development and can be divided into basic research, applied research and experimental development [1]. Therefore, S \& T achievements should include the results arising out from these $\mathrm{S} \& \mathrm{~T}$ activities. However, according to the $\mathrm{S} \& \mathrm{~T}$ achievements appraisal, management, promotion approaches, laws and regulations introduced by China in the past years, the $S$ \& $\mathrm{T}$ achievements are only limited to the creative results with academic significance and practical value and generated from research and development activities.

Later, China attaches more and more importance to the soft science. Soft science achievements are also listed into S \& T achievements. Scientific and technological achievements fall into three categories: scientific theoretical achievements, the applied technological achievements and soft science achievements. Applied technology achievements are suitable for S \& T achievements transformation, and scientific theoretical achievements are considered as fundamental research and such research aims to explore the basic principles of science or knowledge, other than caters for any special or specific application areas, and some theoretical achievements can not be transformed at all. Although soft science achievements play an important role in advancing scientific decision-making and modern management, and prompting harmonious development of S \& T, economy and society, $\mathrm{S} \& \mathrm{~T}$ achievement transformation focuses on $\mathrm{S} \& \mathrm{~T}$ innovation and application. Therefore, S \& T achievements transformation as referred to in this Paper means follow-up experiments, development, application and popularization of S \& T achievements obtained from scientific research and technological development and endowed with practical value, so as to create or achieve new technology, process, materials, products and new industries, thus improving productivity.

\section{Sichuan Provincial State-Owned Enterprises' Problems and Shortcomings in Terms of S \& T achievements Transformation}

In recent years, Sichuan provincial state-owned enterprises shoulder the mission to promote development of economy and society across the Province, and play a supporting and leading role in independent R \& D, introduction, absorption and re-innovation of updated technologies, and industry-university-research cooperation, and achieve reasonable success. For example, these provincial state-owned enterprises successfully transformed many S \& T achievements in electronic information, metallic ore mining, rail transportation, ecological recycling economy and other fields. However, there are still some problems and shortcomings in this respect.

1) Industrial structure is not reasonable. Provincial state-owned enterprises take a high proportion in basic industries but a low proportion in the advanced technology industry and emerging industries. By the end of 2012, 
the assets of Sichuan provincial state-owned assets allocated to basic industries, general production \& processing industry account for about about $82.4 \%$ and $10.9 \%$ of the total assets, but such asset allocation proportion of provincial state-owned enterprises supervised by the SASAC (State-owned Assets Supervision and Administration Commission) was respectively about $46.9 \%$ and $12.9 \%$. Only about $19 \%$ of Sichuan provincial state-owned enterprises capitals were allocated to advanced technology industries and strategic emerging industry. Most of the state-owned enterprises stay at the low end of industry chain featured by low product added value, meager profits, less $S \& T$ research and insufficient application of $S \& T$ achievement. In addition, these enterprises made slow exploration to high-end fields in the industry chain, and have weak bargaining power at the upstream \& downstream of the industries; as a consequence, the industrial competitiveness of these provincial state-owned enterprises is adversely influenced.

2) Structural organization of state-owned is overstaffed and decision-making process is complicated, going against quick decision-making and resulting in delayed market response. Since enterprise size is big, organizational structure complicated and the department functions are not divided clearly, S \& T achievement transformation will involve miscellaneous formalities including project initiation, review and implementation. Furthermore, the current appraisal methods formulated by the state-owned enterprises also discourage enterprises leaders to assume risks and often seek excessively stable development, thus losing opportunities and delaying decision-making.

3) Incentive measures is not effective. All state-owned enterprises develop evaluation criteria in relation to the value preservation and increase of state-owned assets, However, considering the uncertainty of $\mathrm{S} \& \mathrm{~T}$ achievements transformation, the enterprise leaders, who desire to improve innovation capability through $S$ \& $T$ achievement transformation but face huge risk arising from $S \& T$ transformation, especially are restricted by inadequate state-owned enterprises incentives, show obscure attitude in preparing incentive measures.

4) State-owned enterprises develop less cooperation with scientific research institutions fail to effectively combine industry-university-research and have weak innovation capability. First, the independent innovation environment is unsatisfactory. According to the current situation, most of Sichuan provincial state-owned enterprises have not yet specially prepared strategic plans pertinent to independent innovation, and have not effectively combined innovation with enterprises development. Second, the basic material conditions for innovation are weak. According the current situation, the Sichuan provincial state-owned enterprises witness low profitability and fails to develop any innovative activities with high investments and huge risks. Furthermore, these enterprises do not have competent R\&D talents, especially the leading figures who can control technological innovation orientation and are also capable to organize and implement technological innovation [2]. Third, innovation systems are not developed well. The market-oriented technological innovation combining industry-universityresearch-application has not been established, and the talent incentive systems have not been improved. Research and development institutions are insufficient and effective system support unavailable [3]. Assessment measures formulated by the scientific research institutes mainly focus on vertical subject other than enterprises application horizontal subject, showing obvious myopia effect [4]. Effective industry-university-research cooperation is not enough.

5) Financing means is single. S \& T achievements transformation requires a large amount funds. However, the government agencies and banks generally provide funds only for R \& D and industrialization stages [5], and financing from capital markets cannot provide the enterprises with effective funding support in relation to science \& technology research and development. Most of Sichuan provincial state-owned enterprises alleviate pressure of funds by relying on bank loans, and a few of state-owned enterprises raise funds through issuing corporate bonds or capital markets. Therefore, these enterprises are challenged by huge funding pressure. Furthermore, the enterprises are ineffective in expanding external financing channels.

\section{Countermeasures and Suggestions for S \& T Achievements Transformation of Sichuan Provincial State-Owned Enterprises}

\subsection{Striving to Build High-End Industrial Chain and Optimizing Industrial Structure}

S \& T achievements transformation aims to develop high-end industries, build a high-end industrial chain, promote technological progress, thus achieving integrative growth. In light of the feature that the industrial structure of Sichuan provincial state-owned enterprises accounts for a small proportion in advanced technologies and emerging industries, we can, by horizontal and vertical integration, improve the proportion and share of the 
state-owned enterprises engaged in advanced technologies and emerging industries.. In respect of transverse integration of industrial chain improving enterprise concentration, we should integrate the enterprises of same kind in the industry with scale merit by means of $\mathrm{M} \& \mathrm{~A}$, equity cooperation and asset reorganization, thus improving the control ability and influence of state-owned enterprises upon markets. In respect of vertical integration of industrial chain concerning industry transformation \& upgrade, the S \& T achievement can play a better role in completed industrial chain and boost up economic benefit. Therefore, the state-owned enterprises shall actively expand the upstream \& downstream of the industries; make more efforts to control the key link of the industrial chain, so as to achieve integrative development of the industrial chain. For example, provincial pharmaceutical groups shall expand business toward upstream fields like biological medicine planting bases, and make backward integrative development, namely, applying herb planting and production S \& T achievements into production \& operation. While speeding up establishment of agricultural industrial bases, Sichuan provincial stateowned assets company and Sichuan crop group shall achieve forward integrative development through M \& A and controlling of downstream distribution channels, in a bid to improve the economic benefits. Regarding split of industrial chain based on operating efficiency, for the state-owned enterprises which cover several industrial links and responsibility division efficiency is lower than market division efficiency, such provincial enterprises or business thereof at the ineffective industrial chain shall be split. Operating costs shall be reduced via market division, thus improving the enterprise core competitiveness and specialization degree.

\subsection{Making More Efforts to Undertake Research and Development, and Improving the Quality of S \& T Achievements}

First, to improve innovation ability. More efforts shall be done to achieve the coordinated and synchronous development of integrated capabilities including consolidation,, research and development, integration and learning. We should focus on development of high-end industries and provide the production-based and building construction enterprises (like Sichuan Chemical Industry Holding (Group) Co., Ltd., Huashi Group, Sichuan Coal Industry Group Co., Ltd.) with great support to invest more in tackling key problems, thus achieving important breakthrough in terms of new processes and products. Second, to intensify innovation strategy management; we should, by focusing on enterprise development strategies and controlling S \& T innovation direction, prepare scientific S \& T plans and strategies, and strive to realize effective combination, synchronous implementation, assessment and supervision and integrative advancement of S \& T innovation plans and development plan, S \& T innovation strategy and development strategy, so as to ensure the S \& T innovation capability and level can be improved rapidly. Third, to build steady industry-university-research alliance. We should emphasize combination of industry-university-research supply and demand, and provide the enterprises with support in applying for national major S \& T projects, “973” program and "863” program; encourage establishment of jointed enterprises-university-institutes; and establish enterprise R \& D organizations with obvious industrial characteristics and accurate market positioning by means of merge and acquisition of domestic \& overseas R \& $\mathrm{D}$ agencies. In addition, we should allocate and integrate innovation resources on a market-oriented basis, effectively combine industry-university-research with enterprise as leading role, and speed up establishment of national or provincial engineering technology (research) center to build updated technological innovation alliance [6]. In the meantime, we should provide completed supporting service to facilitate transformation of central government-led enterprises' S \& T achievements in Sichuan Province, and to cultivate strategic emerging industries, thus achieving strategic breakthrough in dominant fields. Furthermore, major projects may play a leading role in relevant industries, thereby improving the effectiveness and efficiency of S \& T achievement transformation.

\subsection{Expanding Financing Channels, and Facilitating the $S$ \& $T$ Achievements Transformation}

\subsubsection{Seeking to Create Capital Allocation Favorable for Financing Assurance}

We should, taking effective concentration of provincial state-owned capital as core, focus on structural adjustment of state-owned capitals to realize reasonable allocation and provide financing assurance for the transformation of provincial state-owned enterprises' S \& T achievements [7]. The approaches are set forth as follows: first, provincial state-owned capitals shall be mainly allocated toward the industries and fields represented by industrial investment \& financing platforms like Sichuan Development Holding Co., Ltd. Sichuan Transportation Investment Co., Ltd., Sichuan Energy Investment Co., Ltd., Sichuan Railway Industry Investment Group Co., Ltd., 
and Sichuan Chuantou Water Group Co., Ltd., so as to give full play to the role of the provincial investment \& financing platform; second, the provincial state-owned capitals shall be mainly allocated to large-size provincial enterprises and groups that take a leading place in independent innovation, establish flexible operating systems and have powerful core competitiveness, so as to facilitate agglomerated development of provincial enterprises; third, the provincial state-owned capital shall be mainly allocated to the advantaged industries and special enterprises achieving outstanding performance in market competition, and encourage provincial state-owned enterprises improve their competitiveness by using market means; fourth, provincial state-owned capitals shall be further invested to the main line of business of the provincial state-owned enterprise, in order to improve the scale merit of main line of business of the provincial enterprises.

\subsubsection{Advancing Securitization Progress of Provincial Enterprises Assets by Combining Industry and Financing}

To provide fund support for transformation of S \& T achievements in respect of capital financing, appropriate measures shall be taken to combine industries and financing, and improve allocation efficiency of provincial enterprise resources, advance securitization progress of provincial enterprises assets, and seek breakthrough from banks, trusts and industrial funds [8]. 1) In respect of banks' financial support, at present, the provincial enterprises heavily rely on bank loans. Against the background of macro economy, our own provincial commercial banks are required to support the enterprise development. 2) In respect of expansion of quasi financing business like trust, currently, the overall assets securitization of provincial state-owned enterprise stays at a low level, considering this, we should assist qualified provincial state-owned enterprise in listing for raising funds, and promote combination of industries and financing by leveraging other non-capital market means, thus seeking breakthrough in securitization progress of provincial enterprises asset. 3) In respect of fund support, we should develop, taking industries \& financing interaction as starting point, innovative methods combining industry funds and provincial enterprises, so as to enable the industrial funds to provide different provincial enterprises with fund support. Such methods include: first, to establish provincial investment funds and fund clusters covering all industries by taking industry revitalization \& development investment funds, and to advance the potential provincial state-owned enterprises to collect funds and absorb resources, support major products; boost up development of major business and strategic transformation. Second, to establish a 1 billion Yuan of industrial investment private fund catered for medium \& small provincial enterprise. Such fund shall be mainly applied toward the advanced technological products of provincial enterprises and special enterprises, so as to improve the enterprises' business incubation and capital utilization capabilities. Third, more efforts shall be done to develop the economy of Sichuan Province by use of our own financial assets, and to intensify integration and cooperation of external funds and asset, thus improving funding business in a rapid way.

\subsubsection{Encouraging State-Owned Enterprises Make Multi-Level S \& T Investments}

To meet research and development requirements, most of enterprises and group companies are required to apply part of the science and technology funds toward R \& D of prospective and overall projects. At present, relevant governmental agency lists the $S \& T$ funds withdrawn by group companies from their branches and subsidiaries into group income by operating activities, in this case, the group $S \& T$ investment may subject to repetitive tax. In light of this, relevant governmental agency is expected to introduce new policy, encouraging group companies to make multi-level S \& T investments, and repealing the provision levying repetitive tax upon the S \& T funds withdrawn by group companies from their branches and subsidiaries.

\subsection{Implementing Mixed Ownership Reform, Enhancing Incentive Effect and Optimizing Decision-Making Process}

Mixed ownership economy that is formed through cross shareholding and mutual integration of state-owned capitals, collective capitals and non-public capitals is not only favorable for expanding functions, value preservation and increase of state-owned capitals, improving competitiveness, but also for mutual complementarity, mutual promotion and development. The entities adopting mixed ownership system can absorb the advantages of private enterprises and foreign-funded enterprises in respect of organizational structure setting, employee incentive, S \& T achievement transformation and market response. Mixed ownership economy is favorable for assisting the state-owned enterprises building the consciousness of innovation and competitiveness, thus optimizing organizational structure, improving incentive effect and increasing the efficiency of $\mathrm{S} \& \mathrm{~T}$ achievement 
transformation, decision-making and implementation.

\subsection{Optimizing Corporate Governance Structure, Encouraging Enterprises to Implement S \& T Achievement Transformation}

S \& T achievements transformation achieves the real industrialization and commercialization effect only taking market as orientation. Facing fierce competition, enterprise leaders must have market-oriented concept and consciousness, optimize corporate governance structure, organizational structure and establish reasonable assessment and incentive measures, so as to advance market-oriented $S \& T$ achievement transformation by the enterprises [9]. For this end, the state-owned enterprises' governance structure shall be of market-orientation, standardization and administration.

\subsection{Giving More Preferential Governmental Policy Support and Facilitating Further Industry-University-Research Cooperation}

In 2012, Dong Jie and others researched the efficiency and effect of S \& T achievement transformation to 31 provinces and municipalities in China. The conclusion so drawn indicates that governmental support exerts the most influence upon the S \& T achievement transformation, and several factors like funds, policies and service platform may influence $S \& T$ achievement transformation. Preferential policy shall be provided to optimize the transformation environment and provide support for S \& T achievement transformation [10]. such as clearly determining industrialization implementation subject, supporting crucial technological breakthrough, organizing industrial cooperation, facilitating demonstrative application, establishing S \& T achievement transformation platform and effectively carrying out relevant policies, building industry-university-research-application diversified-subject industrialization working system driven by unified governmental planning, and advancing further industry-university-research cooperation.

\subsection{Expanding the S \& T Insurance Coverage, Reducing Risk from S \& T Achievement Transformation}

Insurance has three major functions: economic compensation, financing and social management, and can play an important role in supporting scientific \& technological progress and innovation, building innovation-oriented country and city, and reducing the risk arising from the $\mathrm{S} \& \mathrm{~T}$ achievement transformation. $\mathrm{S} \& \mathrm{~T}$ insurance is a product combining $S \& \mathrm{~T}$ with insurance, and can provide powerful support for independent innovation and sustainable development, favorable for creating sound scientific \& technological innovation entrepreneurship environment [11]. The Ministry of Science and Technology and China Insurance Regulatory Commission jointly determined Beijing, Tianjin, Chongqing, Wuhan, Shenzhen and Suzhou High-tech Zone as the first batch of science \& technology insurance pilot cities (districts), and launched six S \& T insurance types: high-tech enterprise product R \& D liability insurance, crucial R \& D equipment insurance, business interruption insurance, export credit insurance, officer and key R \& D fellow heath insurance and casualty insurance. Chengdu was determined as one of the second batch of S \& T insurance pilot cities. S \& T departments shall utilize the S \& T insurance as important measure to push forward $\mathrm{S} \& \mathrm{~T}$ progress and innovation, enlarge $\mathrm{S} \& \mathrm{~T}$ insurance coverage and functions and reducing risks arising from $\mathrm{S} \& \mathrm{~T}$ achievement transformation.

\section{References}

[1] He, D.F. (2011) Analysis of and Considerations on the Concepts of Scientific and Technological Achievements and Its Transformation. China Soft Science, 11, 1-7.

[2] (2016) Accelerate the Transformation of Scientific and Technological Achievements and Technology Transfer to Promote the Implementation of Innovation Driven Development Strategy. Economy Affairs, 3, 10-12.

[3] Wu, D. (2016) Study on the Main Problems and Countermeasures in the Implementation of Technological Achievement Transfer Policy. Innovation Science and Technology, 4, 14-17.

[4] Liu, A. (2011) Study on the Triple Helix Model of the Transformation of Scientific and Technological Achievements in China-Taking CAS as an Example. Research in Science Studies, 8, 1129-1134.

[5] Li, M.Z. (2012) The Countermeasures and Proposals for Promoting the Transformation of S \& T Achievements in Zhejiang. Scientific and Technology Management Research, 15, 34-37. 
[6] Pan, D.H. and Sun, C. (2013) Innovation Performance Evaluation of Industry Technology Innovation Strategic Alliance. Science Research Management, S1, 296-301.

[7] Huang, Q.H. (2016) The Layout of State Owned Capital under the New Normal State. China Finance, 4, 21-23.

[8] Su, Y. (2016) The Influence of the Combination of Production and Finance on the Financing of Enterprise Group. Knowledge Economy, 1, 63.

[9] Wu, K.J. (2014) On the Relevant Measures to Promote the Cooperation of Industry University Research and University Research Cooperation. China New Technologies and Products, 6, 158.

[10] Dong, J. and Huang, F.J. (2012) Research on Transformation Efficiency of Sci-Tech Achievements and Its Influence Factors-An Empirical Analysis Based on Stochastic Frontier Function. Soft Science, 10, 15-20.

[11] Xue, W.X., Liu, Q. and Liu, J. (2013) Study on the Effect of Technology Insurance on Technology Enterprises Innovation and Profit Ability. Science \& Technology Progress and Policy, 24, 95-99.

\section{Submit or recommend next manuscript to SCIRP and we will provide best service for you:}

Accepting pre-submission inquiries through Email, Facebook, Linkedin, Twitter, etc A wide selection of journals (inclusive of 9 subjects, more than 200 journals)

Providing a 24-hour high-quality service

User-friendly online submission system

Fair and swift peer-review system

Efficient typesetting and proofreading procedure

Display of the result of downloads and visits, as well as the number of cited articles

Maximum dissemination of your research work

Submit your manuscript at: http://papersubmission.scirp.org/ 